\title{
Justice and Desert in Liberal Theory
}

\author{
Samuel Scheffler $\dagger$
}

Contemporary liberal theory appears to attach relatively little importance to the concept of desert. John Rawls's A Theory of Justice is exemplary in this respect. Rawls explicitly argues that desert has only a derivative role to play in an adequate account of distributive justice, and he is frequently interpreted as advocating a purely institutional theory of desert, according to which people's deserts are in general to be identified with their legitimate institutional expectations. This threatens to deprive the concept of desert of its critical, normative force. Yet Rawls explicitly suggests that desert has a more substantial role to play in retributive than in distributive justice. Even in the case of distributive justice, moreover, he stops short of endorsing a purely institutional theory of desert. This Essay reexamines the idea that there is an asymmetry between distributive and retributive justice with respect to the role of desert. It calls attention to a neglected rationale for that idea and, in so doing, it suggests that egalitarian liberals like Rawls need not endorse the kind of wholesale skepticism about desert that has sometimes been attributed to them.

\section{INTRODUCTION}

Contemporary liberal theory appears to attach relatively little importance to the concept of desert. John Rawls's $A$ Theory of Justice 1 is exemplary in this respect. Rawls explicitly argues that desert has only a derivative role to play in an adequate account of distributive justice, and he is frequently interpreted as advocating a purely institutional theory of desert, according to which people's deserts are in general to be identified with their legitimate institutional expectations. If a just institution has announced that it will attach rewards or penalties to behavior of a certain kind, then according to a purely institutional theory, people who engage in

Copyright (C) 2000 California Law Review, Inc. California Law Review, Incorporated (CLR) is a California nonprofit corporation. CLR and the authors are solely responsible for the content of their publications.

$\dagger \quad$ Class of 1941 World War $\Pi$ Memorial Professor of Philosophy and Law, University of California, Berkeley, Department of Philosophy and School of Law (Boalt Hall).

1. JOHN RAWLS, A THEORY OF JUSTICE (1971). 
such behavior may be said to deserve the rewards or penalties in question. But claims of desert are always dependent in this way on a prior conception of justice and on the expectations actually established by just institutions. There is no independent principle of desert that provides a normative standard for the design of social institutions themselves. There is, according to a purely institutional theory, no legitimate form of "preinstitutional desert."

Although Rawls certainly insists on the derivative role of desert in relation to distributive justice, the ascription to him of a general theory of desert of the kind just described is difficult to reconcile with his stated views about the purposes of the criminal law, and with his explicit suggestion that desert has a more substantial role to play in relation to retributive justice. Indeed, even where distributive justice is concerned, I believe that it is misleading to describe Rawls as defending a purely institutional account. Yet the tendency of many readers to discount or downplay Rawls's remarks about the differences between distributive and retributive justice does not result from simple misreading. Instead, Rawls himself seems to encourage this tendency, for he makes statements about the relation between desert and distributive justice that seem generalizable to the case of retributive justice as well. In other words, the logic of Rawls's argument threatens to carry him beyond the position that he explicitly advocates. Thus, if he is taken to endorse a purely institutional view of desert in the context of distributive justice, the apparent generalizability of his argument from the distributive to the retributive case makes it easy to construe him as committed to a general theory according to which desert is always to be identified with legitimate institutional expectations. ${ }^{2}$ Since such a theory appears to represent a radically revisionist position, which clashes sharply with our ordinary understanding of desert, this in turn contributes to the widespread perception that egalitarian liberals like Rawls are committed to wholesale skepticism about the moral importance of desert. ${ }^{3}$

2. Indeed, I interpreted him in much this way in Responsibility, Reactive Attitudes, and Liberalism in Philosophy and Politics, 21 PHIL. \& PUB. AfF. 299 (1992).

3. There are many writers who ascribe this kind of skepticism to Rawls. For cxample, Michael Sandel says it is Rawls's view that, "strictly speaking, no one can be said to deserve anything." Michael J. SANDEl, LiberalisM AND THE Limits of JuSTiCe 88 (1982). George Sher interprets Rawls as arguing "that nobody (pre-institutionally) deserves anything." GEORGE SHER, DESERT 20 (1987). And Alan Zaitchik finds in Rawls "a completely general argument which alleges that no desert theory could be true for the simple reason that no one ever deserves anything." Alan Zaitchik, On Deserving to Deserve, 6 PhIL. \& PuB. AfF.370, 371 (1977). In Responsibility, Reactive Attitudes, and Liberalism in Philosophy and Politics, supra note 2, I argued that the influence of naturalism is at least partly responsible for the reluctance of many contemporary liberal theorists (and their critics) to rely on a robust notion of desert. Without wishing altogether to repudiate this diagnosis-I still think it constitutes one factor among others-I will attempt in this Essay to identify a more positive rationale for hberal skepticism about distributive desert in particular.

One question that I cannot adequately deal with here concerns the role of desert in what Elizabeth Anderson calls "luck egalitarianism," by which she means the view that "the fundamental aim of 
These considerations help to explain why Rawls's treatment of desert has been so controversial. They also suggest that, if liberal theories of justice are to be persuasive, both the sources and the extent of liberal skepticism about desert need to be better understood. In this Essay, I want to reexamine the idea that desert plays a different role in relation to retributive justice than it does in relation to distributive justice. This is Rawls's stated position, and it comports with a very natural interpretation of the difference between the criminal law and the other parts of a legal system. Such an interpretation has been eloquently defended, for example, by Sanford Kadish, whose writings combine an unwavering opposition to attempts to purge the criminal law of notions of culpability and blameworthiness with a measured skepticisin about the use of the criminal sanction to serve the purposes of broader social and economic policy. ${ }^{4}$ Ultimately, I believe that there may be deep moral and philosophical motivations for seeking to de-emphasize desert in relation to distributive justice while retaining it as an element of our thinking about a variety of other topics, including retributive justice and the function of the criminal law. The question raised by the controversy about Rawls's treatment of desert is whether the reasons that generate liberal skepticisin about the concept's distributive relevance can, in the end, be confined to the distributive context, or whether they must inevitably generalize to other areas as well.

I will proceed as follows. In Part I, I will discuss Joel Feinberg's influential essay Justice and Personal Desert, ${ }^{5}$ whose publication preceded by eight years the appearance of Rawls's A Theory of Justice, and on which Rawls relies at several points in his discussion. Drawing on

equality is to compensate people for undeserved bad luck" Elizabeth S. Anderson, What Is the Point of Equality?, 109 ETHICs 287, 288 (1999). Luck egalitarianism may appear to represent an exception to the general tendency within contemporary liberalism to treat desert as having relatively little importance. Yet, for the most part, the writers Anderson has in mind do not explicitly assign a central role to desert. Their main thesis is that material inequalities resulting from people's choices are acceptable whereas those resulting from unchosen circumstances are not. Some of these writers do at times express the negative part of this point by saying that people should be compensated for undeserved bad fortune, a formulation which is meant to preempt conservative objections to egalitarian redistribution by appealing to the truism that people do not deserve, for example, the circumstances of their birth. In this they follow Rawls's own discussion. See infra Part III. Like Rawls himself, however, and pace Anderson's suggestion, see Anderson, supra, at 288-89, such writers generally avoid the positive claim that people deserve the good or bad outcomes that result from their choices. What they tend to say instead is that it is reasonable to hold people responsible for those outcomes. Of course, one might argue, in criticism of this position, that it makes sense to place such weight on the distinction between choices and circumstances only if one is tacitly assuming that people do deserve the outcomes of their choices. This would imply that luck egalitarianism is committed to assigning a more fundamental role to desert than its proponents acknowledge. The writings by liberal theorists that Anderson cites as examples of luck egalitarianism include THOMAS NAGEL, EQuality aND Partiality (1991); ERIC RAKowsKi, Equal Justice (1991); and Ronald Dworkin, What is Equality? Part 2: Equality of Resources, 10 PHIL. \& PUB. AfF. 283 (1981).

4. See Sanford H. Kadish, Blame and Punishment: Essays in the Criminal Law (1987).

5. Joel Feinberg, Justice and Personal Desert, in Nomos VI 69 (Carl J. Friedrich \& John W. Chapman eds., 1963), reprinted in DoING AND Deserving 55 (Joel Feinberg ed., 1970). 
Feinberg's essay, I will explain in Part II why purely institutional theories of desert appear radically revisionary of our ordinary beliefs and why they have seeined objectionable to many people. In Part III, I will review Rawls's own treatınent of desert, including his account of the differences between the role of desert in distributive justice and its role in retributive justice. I will explain why, even in the distributive case, it seems to me misleading to describe Rawls as defending a purely institutional theory. I will also outline an alternative theory, which I call the Liberal Theory, that seems to me to capture Rawls's most important claims while avoiding some of the major objections to institutional accounts. In Part IV, I will explain why, notwithstanding his explicit claims about the asymmetry between distributive and retributive justice, Rawls's view of distributive desert has appeared to be generalizable to the retributive case as well. In Part V, I will suggest a rationale for the view that desert has a less fundamental role to play in distributive justice than it does in retributive justice and, in Part VI, I will reconsider the supposed generalizability of Rawls's conception of desert in light of this rationale. Finally, I will summarize my conclusions and take stock of their significance.

\section{I}

\section{Feinberg ON Justice AND Desert}

Feinberg's discussion is limited to cases of personal desert and, more specifically, to cases in which what a person deserves is some sort of treatment by others. The judgment that a person deserves something, Feinberg says, implies that there is something about the person in virtue of which he or she deserves that thing. This Feinberg refers to as the "desert basis." The desert basis, he says, must be some characteristic of, or fact about, the deserving person, and different kinds of deserved treatment have different desert bases. Feinberg argues that there are five major classes of deserved treatment: (I) awards of prizes; (2) assignment of grades; (3) rewards and punishments; (4) praise, blame, and other informal responses; and (5) reparation, liability, and other inodes of compensation.? He does not include either positions of honor or economic benefits on this list, because he believes that they are ordinarily subsumed under one or more of the other five categories.

Femberg argues that desert functions as a "polar" concept with respect to soine of these categories and as a "nonpolar" concept with respect to others. ${ }^{8}$ When it functions as a polar concept, one can either deserve good or deserve ill. When it functions as a nonpolar concept, one can instead either deserve something or not deserve it. Prizes are said to exemplify

\footnotetext{
6. Id. at 58.

7. See id. at 62.

8. Id.
} 
nonpolar desert. In a game or contest, the winner deserves the prize and the other contestants do not, but there is no further bad thing that the others deserve. There is no negative analogue of the prize. By contrast, rewards and punishment exemplify polar desert, since to deserve punishment is indeed to deserve ill. Rewards, Feinberg says, are conventional means of expressing such attitudes as gratitude, appreciation, and recognition of merit; punishments are conventional means of expressing resentment, disapproval, and condemnation. Feinberg refers to the attitudes thus expressed as "responsive attitudes." He says that these attitudes "have ostensible desert logically built in to them,"10 by which he means that they inust always be experienced as a response to some desert basis-that is, as a response to something about the person who is their object. Thus, he writes, "resentment without an ostensible desert basis is not resentment."11

One of the main themes of Femberg's essay is the difference between desert and institutional qualification or entitlement. In general, to qualify for something is to satisfy the relevant institutional rules governing its distribution. In order to deserve something, however, one inust be worthy of it. Thus "desert," Feinberg says, "is a moral concept in the sense that it is logically prior to and independent of public imstitutions and their rules." 12 Or as he says at another point, "desert is a 'natural' moral notion (that is, one which is not logically tied to institutions, practices, and rules)."13 The distinction between desert and qualification shows up in most of Feinberg's five categories. With respect to prizes, for example, the rules of a competitive game or contest typically specify certain "victory conditions," 14 and the person or team that satisfies those conditions qualifies for and is entitled to the relevant prize. By contrast, the desert basis of a competitive contest "is always preeminent possession of the skill singled out as a basis of competition." So the person who is victorious is not necessarily the person who deserves to win. "In a contest of skill the man who deserves to win is the man who is most skilled, but (because of luck) he is not in every case the man who does win." 16

Despite these differences between desert and entitlement, Feinberg suggests that they may be related in the following way. ${ }^{17}$ The basic things people deserve, he says, are the responsive attitudes that are appropriate to their conduct. However, in many cases we have established institutional
9. Id. at 70 .
10. Id. at 70-71.
11. Id. at 71 .
12. Id. at 87 .
13. Id. at 56 .
14. Id. at 63 .
15. Id. at 64 .
16. Id.
17. See id. at 82-85. 
mechanisms for acknowledging and expressing those attitudes. The institutions in question set forth qualifying conditions that people must satisfy in order to receive the "modes of treatment" 18 that those institutions dispense. The content of the qualifying conditions is shaped by the aim of distributing the relevant modes of treatment in accordance with the appropriate desert bases, so far as possible. In other words, the institutional rules and procedures are set up with the aim of giving people what they deserve. Nevertheless, qualification and desert remain distinct notions that inevitably diverge in some cases. However, a well-designed institution may, on the whole, do a better job of giving people what they deserve than would a generalized practice of expressing all responsive attitudes in an ad hoc, noninstitutionalized manner. Our actual practice does have this informal character in the case of praise and blame, which have no institutional qualifying conditions. Feinberg argues, however, that reliance on institutions to give public and conventional expression to various responsive attitudes may, in general, be a more dependable way of seeing that people get what they deserve.

A related theine that Feinberg exphasizes is the heterogeneity of desert and the variety of forms that conflicts of justice can take. ${ }^{19}$ Desert is not a monolithic factor that, by itself, determines what is just. Claims of desert can conflict with each other and with considerations of institutional entitlement, and these are conflicts within the category of justice. So although one of the proper aims of institutions is to give people what they deserve, justice will sometimes require that people get what they are entitled to rather than what they deserve. Justice may be better served by adhering to a system of institutional entitlement even in cases where desert and entitlement conflict than it would be by directing those who administer the relevant institutions to assign benefits and burdens on a case-by-case basis in accordance with perceived desert.

One final aspect of Feinberg's essay that is relevant for our purposes is his discussion of the relation between desert and economic income..$^{20}$ Here he provides what is, in effect, an argument about the bearing of desert on questions of distributive justice. Feinberg acknowledges that people often say such things as "doctors are paid more than they deserve" or "teachers are paid less than they deserve." He thinks that there are various ways of interpreting such claims, none of which is wholly satisfactory. A large income cannot plausibly be construed as a prize in a coinpetitive contest because there is no unique desert basis of the alleged competition. Construing extra income as a reward rather than a prize is more plausible, but then there is the question of what exactly is being rewarded.

\footnotetext{
18. Id. at 82 .

19. See id. at 79-80.

20. See id. at $88-94$.
} 
Possibilities include moral virtue, talent or ability, and contributions to economic welfare or the quality of life. However, Feinberg sees difficulties with all of these suggestions. In the end, he argues that economic income can plausibly be said to be deserved only insofar as it can be construed as compensation. Thus, those who have unusually hazardous or onerous jobs may deserve compensation in the form of extra income. In such cases, he argues, desert plays an egalitarian role, for the function of the deserved coinpensation is to restore an equality of net benefit. In fact, Feinberg claims, from the fact that income is deserved only insofar as it is compensation, it follows that to "say that incoine ideally ought to be distributed only according to desert is to say that, im respect to all social benefits, all men should ideally be equal."21 This does not mean that everyone should in fact be equal, only that any considerations there may be in favor of inequality will have "nothing to do with desert."22 For example, the prospect of extra incoine may serve as an incentive to engage in socially valuable activities and may help to create sufficient wealth that even those with smaller incomes end up with more than they would have received under a strictly egalitarian regime. If so, Feinberg suggests, this is a consideration that may in principle take priority over considerations of desert and provide a legitimate basis for economic inequality.

It is worth noting, however, that if income is deserved only insofar as it is coinpensation for unusually hazardous or burdensome work, then, contrary to what Feinberg claims, it does not follow that considerations of desert support an egalitarian distribution of income. What follows instead is that only people who perform unusually hazardous or burdensome work deserve any income at all. This, in turn, would seem to imply that the idea that incoine should be distributed solely according to desert is not an egalitarian idea but rather an absurd one. The saine point may be put another way. If income is deserved only insofar as it is compensation for unusually hazardous or burdensome work, then it may be said that the function of deserved incoine is to restore the people who perform such work to their proper position im whatever distribution of benefits is treated as a normative baseline. However, considerations of desert do not, on this interpretation, dictate that the baseline itself should be an egalitarian one. Instead, they are simply silent about what the baseline should be.

II

ObJections to the PuRely Institutional Theory

If, as Feinberg argues, desert is normally understood as "a moral concept in the sense that it is logically prior to and independent of public

21. Id. at 94 .

22. Id. (emphasis removed). 
institutions and their rules, ${ }^{, 23}$ then it is clear that a purely institutional theory, according to which people's deserts are to be identified exclusively with their legitimate institutional expectations, represents a radically revisionist position. Such a theory is subject to at least four important objections. The first and perhaps the most fundamental of these, which follows directly from the claim that desert is a moral concept in the sense Feinberg specifies, is simply that the theory collapses the distinction between judgments of merit or worth, and judgments of institutional entitlement-the very distinction on whose importance Feinberg insists.

The second objection is that the institutional theory deprives the concept of desert of its critical force. The theory denies that there is any standard of desert that is independent of institutional rules and practices, and relative to which institutions may be found wanting. If an institution honors the expectations generated by its own rules and policies, there can be no basis for any claim that the institution fails to give people what they deserve. Furthermore, since the institutional theory identifies legitimate desert claims with the expectations generated by just institutions, the theory implies that in an unjust society nobody deserves anything. In such a society there will, by hypothesis, be no expectations generated by just institutions. Thus, even if such a society does not honor the expectations generated by its own rules and policies, it cannot be criticized for failing to give people what they deserve.

The third objection is that the institutional theory misconstrues the relationship between the concepts of justice and desert. Whereas Feinberg, in keeping with the traditional view that justice consists in giving each person his or her due, ${ }^{24}$ insists that one of the aims of just institutions is to give people what they may independently be said to deserve, the institutional theory says that what people deserve is whatever just institutions have given them reason to expect that they will receive. The theory thus reverses the traditional order of dependence between the concept of justice and the concept of desert.

The fourth objection is that the institutional theory cannot accommodate the role played by judgments of desert in the expression of important interpersonal attitudes such as gratitude and resentment. As we saw, Feinberg argues that such attitudes "have ostensible desert logically built in to them," ${ }^{26}$ by which he means that they must all be "felt as deserved."27 Furthermore, judgments about what people deserve often serve to express

\footnotetext{
23. Id. at 87 .

24. See, e.g., ARISTotle, Nicomachean Ethics, book V, ch. 3 (Martin Ostwald trans., 1980).

25. See supra text accompanying notes 9-11.

26. Feinberg, supra note 5, at 70-71.

27. Id. at 71 .
} 
these "responsive" or "reactive" attitudes. ${ }^{28}$ For example, the judgment that an individual deserves to be punished for what he or she has done may serve to express our outrage or indignation about that person's deeds. However, the objection runs, the institutional theory cannot accommodate the important expressive role thus played by judgments of desert, for, in the example just given, the content of the attitudes expressed is not that the individual who is the target of our outrage has good reason to expect some punishment. Instead, such attitudes appear to rely on a standard of desert that is independent of institutional entitlements and expectations.

Many critics have regarded these objections as decisive against the purely institutional theory. ${ }^{29}$ Whether or not one accepts this conclusion, the objections help to explain why such a theory strikes most people as representing, at the very least, a radically revisionist way of understanding desert. It also helps to explam why the perception that egalitarian liberalism is committed to a purely institutional view has been an important source of opposition to the liberal position. To a large extent, that perception is based on Rawls's discussion of desert in $A$ Theory of Justice.

\section{III}

\section{RAWLS ON JUSTICE AND DESERT}

A Theory of Justice contams only two discussions of any length that are explicitly about desert. The first of these occurs in Section 17, in the context of an explanation of the sense in which Rawls's "difference principle" ${ }^{30}$ is an egalitarian principle of distributive justice, and one which "expresses a conception of reciprocity." 31 The entire discussion coinprises just two paragraphs, and reads as follows:

There is a natural inclination to object that those better situated deserve their greater advantages whether or not they are to the benefit of others. At this point it is necessary to be clear about the notion of desert. It is perfectly true that given a just system of cooperation as a scheme of public rules and the expectations set up by it, those who, with the prospect of improving their condition, have done what the system announces that it will

28. The term "reactive attitudes" is introduced by Peter Strawson in Freedom and Resentment, reprinted in FREE W1LL 59, 63 (Gary Watson ed., 1982).

29. For some varying assessments of the respective merits of institutional and preinstitutional conceptions of desert, see Geoffrey Cupit, Justice as Fittingness (1996); What Do We Deserve? A Reader on Justice ANd Desert (Louis P. Pojman \& Owen McLeod eds., 1999); and Sher, supra note 3.

30. The difference principle states that social and economic inequalities are to be arranged in such a way that they are to the greatest benefit of the least advantaged members of society. The principle implies, for example, that it is just to pay higher salaries to some people than to others if and only if this serves to maximize the position of those who have least, perhaps by giving those who are better paid an incentive to engage in socially valuable activities. See RAWLs, supra note 1, at 75-83.

31. Id. at 102 . 
reward are entitled to their advantages. In this sense the more fortunate have a claim to their better situation; their claims are legitimate expectations established by social institutions, and the community is obligated to meet them. But this sense of desert presupposes the existence of the cooperative scheme; it is irrelevant to the question whether in the first place the scheme is to be designed in accordance with the difference principle or some other criterion.

Perhaps some will think that the person with greater natural endowments deserves those assets and the superior character that made their development possible. Because he is more worthy in this sense, he deserves the greater advantages that he could achieve with them. This view, however, is surely incorrect. It seems to be one of the fixed points of our considered judgments that no one deserves his place in the distribution of native endowments, any more than one deserves one's initial starting place in society. The assertion that a man deserves the superior character that enables him to make the effort to cultivate his abilities is equally problematic; for his character depends in large part upon fortunate family and social circumstances for which he can claim no credit. The notion of desert seems not to apply to these cases. Thus the more advantaged representative man cannot say that he deserves and therefore has a right to a scheme of cooperation in which he is permitted to acquire benefits in ways that do not contribute to the welfare of others. There is no basis for his making this claim. From the standpoint of common sense, then, the difference principle appears to be acceptable both to the more advantaged and to the less advantaged individual. Of course, none of this is strictly speaking an argument for the principle, since in a contract theory arguments are made from the point of view of the original position. But these intuitive considerations help to clarify the nature of the principle and the sense in which it is egalitarian. ${ }^{32}$

This passage is the primary source of the impression that Rawls favors a purely institutional theory of desert. Clearly, however, he does not explicitly avow such a theory here. Instead, he purports to be offering an "intuitive" response-as opposed to an argument from the standpoint of the parties in the hypothetical choice situation that he calls the "original position"33 - to one possible objection to his difference principle. The objection is that those who are relatively well-off deserve greater benefits than they would be assigned by the difference principle, which insists that

32. Id. at 103-04.

33. The original position is a hypothetical choice situation in which rational agents who are concerned to further their own interests but who do not know their specific identities or circumstances are asked to choose principles of justice to regulate the basic structure of their society. See id. at 11-17. 
any extra economic advantages enjoyed by those who are better off must benefit those who are worse off.

In responding to this objection, Rawls makes at least four claims. The first is that, although people are entitled to whatever benefits just institutions have led them to expect, and although they may in that sense be said to deserve those benefits, it is clear that no appeal to institutional expectations can vindicate an objection to the difference principle or, indeed, to any other candidate principle of justice. The legitimacy of such expectations itself depends on a prior conception of justice. The second claim is that people cannot properly be said to deserve their natural talents or traits of character. The third claim is that, accordingly, those who are better situated cannot argue that they deserve their greater economic advantages because they deserve the personal traits that enabled them to secure those advantages. The argument fails because the preimse is false. ${ }^{34}$ The fourth claim is that, because the better situated do not deserve their personal traits, neither can they be said to deserve the establishment of institutions that would give special advantages to people who possess those traits.

It is not difficult to see how one might get the impression that Rawls is advocating an institutional theory of desert in this passage. To begin with, his statement that "it is necessary to be clear about the notion of desert"35 inakes it seem as if the sentences that follow are meant to provide general conceptual clarification-to unpack the concept of desert. Since those sentences proceed to affirm the significance of legitimate institutional expectations, while rejecting certain kinds of noninstitutional desert claims, Rawls may appear to be insisting that desert is, as a conceptual matter, to be identified exclusively with the expectations generated by just institutions. Yet it is worth emphasizing that Rawls stops short of endorsing the institutional theory or of rejecting preinstitutional desert in general. In other words, he does not say that claims of desert are legitimate only insofar as they are understood in purely institutional terms, nor does he say that there is no place at all for a preinstitutional notion of desert.

The significance of these omissions will be easier to assess after looking at Rawls's second extended discussion of desert, which occupies the whole of Section 48 (entitled "Legitimate Expectations and Moral Desert"). By this point in the book, he has coinpleted the presentation of his two principles of justice, outlimed the main arguinents for the adoption of those principles by the parties in the original position, and sketched a system of institutions that satisfies the two principles. In the section

34. This claim corresponds roughly to what Robert Nozick, in his catalogue of possible interpretations of various of Rawls's arguments, refers to as the rebuttal of "counterargument E." RoBERT NozICK, ANARCHY, STATE, AND UTOPIA 224 (1974).

35. RAWLS, supra note 1 , at 103. 
that immediately precedes the discussion of desert in Section 48, Rawls takes up the question of how well his conception of justice accords with various "common sense precepts of justice."36 Section 48 extends this discussion by considering the common sense tendency to suppose "that income and wealth, and the good things in life generally, should be distributed according to moral desert." ${ }^{\text {37 }}$ It seems clear that by "moral desert" Rawls means desert for which the desert basis is moral virtue or worthiness. He argues that the principle of distributing economic benefits in accordance with moral desert is not acceptable and would not be chosen in the original position. He offers several reasons in support of these claims.

The first reason is simply that "the notion of distribution according to virtue fails to distinguish between moral desert and legitimate expectations." ${ }^{38}$ Ironically, this echoes one of the main objections to the institutional theory of desert. Rawls's complaint is that, in treating desert as privileged, the principle of distribution in accordance with virtue assigns desert the role properly played by legitimate expectations. The institutional theory is said by its critics to do just the opposite; in treating legitimate expectations as privileged, it assigns them the role properly played by desert. In both cases, however, the alleged effect is the same, namely, to collapse the distinction between desert and legitimate expectations.

Rawls's second reason is that the principle of distribution in accordance with moral desert is "impracticable." ${ }^{\text {"39 }} \mathrm{He}$ makes this point in the context of considering the common sense precept "which seems intuitively to come closest to rewarding moral desert"-namely, the precept that recommends "distribution according to effort, or perhaps better, conscientious

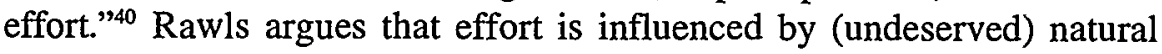
abilities, since "the better endowed are more likely, other things being equal, to strive conscientiously." ${ }^{\text {"1 }}$ Moreover, we have no feasible method for ascertaining the extent to which a person's conscientious efforts are attributable to his or her virtuous character and the extent to which they are the result of valuable but undeserved natural abilities. For practical purposes, the two factors are impossible to disentangle, yet only the former is plausibly seen as an indicator of moral desert. Accordingly, Rawls concludes, "[t]he idea of rewarding desert is impracticable." 42

\footnotetext{
36. Id. at 304 .

37. Id. at 310 .

38. Id. at 311 .

39. Id. at 312 .

40. Id.

41. Id.

42. Id.
} 
The third reason is that the notion of moral desert or worth itself presupposes a prior conception of justice and cannot, accordingly, provide the basis for such a conception. The "concept of moral worth does not provide a first principle of distributive justice . . . because it cannot be introduced until after the principles of justice . . . have been acknowledged." ${ }^{33}$ To be morally worthy, Rawls argues, is to have a strong sense of justice; thus "the concept of moral worth is secondary to those of right and justice, and it plays no role in the substantive definition of distributive shares."44 To emphasize this point, Rawls draws an analogy between the relation of justice and desert, on the one hand, and the relation of property and theft, on the other. "For a society to organize itself with the aim of rewarding moral desert as a first principle would be like having the institution of property im order to punish thieves." 45

Finally, Rawls argues that the parties in the original position would reject the principle of distribution in accordance with moral desert even if there were some standard for assessing desert that was independent of and prior to justice. ${ }^{46}$ Since the parties are interested only in maximizing their own shares of primary social goods, such a principle would have little appeal for them.

After presenting these arguments, Rawls goes on to make his claim that there is an important asymmetry between distributive and retributive justice. ${ }^{47}$ The appeal of the principle of distribution in accordance with moral desert, he suggests, may rest on a failure to appreciate this asymmetry. Citing Feinberg for support, he characterizes the asymmetry as follows. The purpose of the criminal law, he says, is to uphold natural duties, and acts that are prohibited by criminal statutes are normally wrong quite apart from their illegality. "Thus," Rawls writes, "a propensity to commit such acts is a mark of a bad character, and in a just society legal punishments will only fall upon those who display these faults." 48 However, he argues, it would be a mistake to suppose that distributive justice is "soniehow the opposite" 49 of retributive justice. That is, it would be a mistake to suppose that a just distributive scheme rewards people who are morally worthy or deserving in much the sanie way that a just legal system punishes people of bad character who have violated their natural duties. Instead, Rawls argues, the purpose of a just distributive scheine is to establish a social framework within which people can pursue their diverse aims without producing results that are incoinpatible with the demands of

\footnotetext{
43. Id.

44. Id. at 313 .

45. Id.

46. See id.

47. See id. at 315 .

48. Id.

49. Id. at 314 .
} 
fairness and efficiency. ${ }^{50}$ Toward this end, such a scheme may give some people larger shares in order to "cover the costs of training and education, to attract individuals to places and associations where they are most needed from a social point of view, and so on." ${ }^{51}$ However, the assignment of these shares has nothing to do with the moral worthiness of the people who receive them. Thus, to "think of distributive and retributive justice as converses of one another is completely misleading and suggests a different justification for distributive shares than the one they in fact have." 52

Rawls's discussions in Sections 17 and 48 pose a variety of interpretive puzzles that I shall not attempt to address. ${ }^{53}$ Instead, I want to identify three elements that seem to me to constitute the core of Rawls's view, and the conjunction of which I will (tendentiously) refer to as the "Liberal Theory" of desert. First, the Liberal Theory holds that an adequate account of distributive justice must affirm the validity of legitimate institutional expectations. People are entitled to the economic benefits that just institutions lead them to expect, and insofar as claims of desert are nothing more than claims of institutional entitlement they may in principle be perfectly legitimate. Second, according to the Liberal Theory, there is no legitimate notion of desert that is prior to and independent of the principles of distributive justice themselves, and by reference to which the justice of institutional arrangements is to be assessed. There is, in other words, no legitimate form of prejusticial desert. Distributive justice does not consist in giving people what they may independently be said to deserve. Third, however, the Liberal Theory takes a different view of retributive justice. Whereas a just distributive scheme cannot coherently seek to reward moral desert, those whom the criminal justice system legitimately punishes have normally done something that would be wrong even in the absence of a law prohibiting it. Thus, people who are justly punished are normally unworthy or undeserving, as judged by a standard that is independent of the principles of just punishment themselves. In this sense, just retributive

50. See id. at 315 .

51. Id.

52. Id.

53. One puzzle concerns Rawls's understanding of the relation betwcen "moral desert" and desert simpliciter. He uses the term "moral desert" in Section 48 but not in Section 17. The question is whether his references to desert in the earlier section should also be understood as references to moral desert (that is, to desert for which the desert basis is moral virtue or worth). If so, then Section 17 would be claiming, for example, that people do not morally deserve their natural talents. Thomas Pogge suggests that this is the correct interpretation of Rawls's argument. He says that, in general, "Desert, for Rawls, is moral deservingness, a reflection of one's moral worth in virtue of which alone one can Deserve anything." Thomas W. Pogge, Realizing Rawls 77 (1989). If Pogge's interpretation is correct, it exposes Rawls to the obvious objection that there are many morally relevant desert claims that do not have moral virtue as their desert basis. Rawls's reference to "a familiar although nonmoral sense" of desert, supra note 1, at 314, seems intended to allow for such claims, but it confuses matters by eliding the difference between lacking a moral desert basis and lacking moral relevance. 
institutions may indeed be responsive to a conceptually independent conception of desert.

In short, the Liberal Theory denies that the principles of distributive justice make reference to a prejusticial notion of desert, but it allows that there may nevertheless be a legitimate place for prejusticial desert in our thinking about retributive justice. This is the asymmetry that I want to explore. Before I do that, however, it is worth emphasizing that, even in the distributive context, the rejection of prejusticial desert and the affirmation of legitimate expectations, taken together, do not imply a purely institutional theory of desert. They do not imply that desert is legitimate only if it is understood institutionally, nor do they imply that there is no legitimate preinstitutional notion of desert. To see this, we have only to observe that it would be compatible with the Liberal Theory to maintain that people deserve whatever economic benefits justice dictates that they should receive. On this view, desert would not be prejusticial, since it would be defined in terms of justice rather than vice versa; nevertheless, it would be preinstitutional, since it would be a normative notion that was independent of actual institutions and their rules, and could be used to assess them. In other words, an unjust institution could be described as failing to give people what they deserve, even though the institution had not violated its own rules or disappointed any expectations it had generated. It seems evident, then, that, even in the context of distributive justice, the Liberal Theory need not collapse the distinction between desert and institutional entitlement, or deprive the concept of desert of its critical force, as a purely institutional theory is said to do. This means that the Liberal Theory can avoid two of the most important objections to a purely institutional view.

Since Rawls never explicitly endorses a purely institutional view in the case of distributive justice; smce he clearly rejects such a view in the case of retributive justice; since the Liberal Theory captures the inost important of Rawls's explicit claims about desert; and since the Liberal Theory can avoid some of the most obvious and most influential objections to a purely institutional view, it seems to me misleading to describe Rawls as defending a purely institutional view even in the distributive case. Although the supposition that he accepts an imstitutional view of distributive desert inay not be inconsistent with anything that he says, it is at the very least an overstatement to describe him as defending such a view. However, my primary concern in this Essay is not with the interpretation of Rawls's text. Although I believe that the Liberal Theory constitutes the core of Rawls's position, I also believe that the theory merits attention whether or not that interpretative claim is correct.

As we have just seen, the Liberal Theory avoids two of the most important objections to a purely institutional view. Yet in denying that 
distributive justice consists in giving people what they may independently be said to deserve-in denying that a prejusticial notion of desert is available in the distributive context-the Liberal Theory does indeed reverse the traditional order of dependence between the concepts of justice and desert, just as a purely institutional theory does. At the same time, of course, the Liberal Theory accepts the traditional order of dependence in the context of retributive justice. ${ }^{54}$ Before suggesting a rationale for this claim of asymmetry, it will be useful to review the reasons why many people have remained unpersuaded by Rawls's own claim of asymmetry, and have felt instead that his treatment of desert and distributive justice must inevitably generalize to the retributive case as well.

\section{IV}

\section{The Generalizability of Rawls's Arguments}

Doubts about Rawls's claim of asymmetry can take either a positive or a negative form. On the positive side, it may seem that Rawls's treatment of desert in the distributive context has a strategic motivation that applies with equal force to the case of retributive justice. In this spirit, for example, T.M. Scanlon maintains that "Rawls's theory of distributive justice" employs "a general philosophical strategy"5s that is equally applicable in both cases:

In approaching the problems of justifying both penal and economic institutions we begin with strong pretheoretical intuitions about the significance of choice: voluntary and intentional commission of a criminal act is a necessary condition of just punishment, and voluntary economic contribution can make an economic reward just and its denial unjust. One way to account for these intuitions is by appeal to a preinstitutional notion of desert: certain acts deserve punishment, certain contributions merit rewards, and institutions

54. Thus, of the four objections to purely institutional theories that were described in Part II, the Liberal Theory avoids the first two and, although it does in part reverse the order of dependence between the concepts of justice and desert (which was the third objection), the rationale I will sketch for the theory, if compelling, would show that this is not in fact objectionable. An interesting question, which I cannot pursue here, is whether the Liberal Theory also avoids the fourth objection to purely institutional views, namely, that they cannot accommodate the "responsive" or "reactive" attitudes. As we saw, many such attitudes are said to depend on a conception of desert that is incompatible with a purely institutional account. This is said to be true particularly of the attitudes that find expression through the institution of punishment. Since the Liberal Theory does not challenge the role of prejusticial desert in retributive justice, it clearly has no difficulty accommodating those attitudes in particular. Yet, as I argued in Responsibility, Reactive Attitudes, and Liberalism in Philosophy and Politics, supra note 2, judgments about the proper distribution of economic advantages may also serve to express attitudes like gratitude and resentment. To the extent that that is so, there remains a legitimate question about the compatibility of the Liberal Theory and the reactive attitudes.

55. T.M. Scanlon, Jr., The Significance of Choice, in THE TANNER LeCTURES ON HuMAN VALUes VIII 149, 188 (Sterling M. McMurrin ed., 1988). 
are just if they distribute benefits and burdens in accord with these forms of desert.

The strategy I am describing makes a point of avoiding any such appeal. The only notions of desert which it recognizes are internal to institutions and dependent upon a prior notion of justice: if institutions are just then people deserve the rewards and punishments which those institutions assign them. In the justification of institutions, the notion of desert is replaced by an independent notion of justice; in the justification of specific actions and outcomes it is replaced by the idea of legitimate (institutionally defined) expectations. ${ }^{56}$

In this passage, Scanlon does not distinguish between preinstitutional and prejusticial desert, and he appears to interpret Rawls as advocating a purely institutional theory of economic desert. For present purposes, however, the important point is that Scanlon sees the cases of distributive and retributive justice as parallel with respect to the role of desert, and that he finds it natural to construe Rawls's treatment of desert in relation to distributive justice as part of a unified philosophical strategy for dealing with both cases.

In a more critical vein, some writers have maintained that the arguments Rawls gives for his view of economic desert, if valid, apply with equal force in the case of retributive justice. ${ }^{57}$ Recall that in Section 17 Rawls makes at least four claims: (1) that no appeal to institutional expectations, however legitimate, can vindicate an objection to the difference principle, (2) that people do not deserve their natural abilities or characters, (3) that those who are relatively affluent cannot, therefore, say that they deserve their greater economic advantages because they deserve the traits that enabled them to secure those advantages, and (4) that, since those who are better situated do not deserve their personal traits, neither can they claim to deserve the establishment of institutions that would reward people who possess such traits. Now those critics who see Rawls's arguments about economic desert as generalizable to the retributive case interpret him as making a fifth and stronger claim as well. They take him to be claiming that since people never deserve their traits and abilities, it follows that they never deserve any of the benefits that those traits might enable them to secure. In effect, these writers interpret Rawls as tacitly relying on a general principle which says that a desert claim cannot be valid unless its underlying desert basis is itself deserved.

As I will imdicate in Part VI, I believe that there is room to question this interpretation of Rawls. For the moment, however, the important point is that those critics who see Rawls's argument as generalizable to

56. Id.

57. See infra text accompanying notes 58-59. 
the retributive case do in fact interpret him in this way. Of course, the putative principle to which they see him as appealing strikes most people as implausible; as Robert Nozick puts the point in Anarchy, State, and Utopia, it 'needn't be that the foundations underlying desert are themselves deserved, all the way down." 58 However, the critics argue, insofar as Rawls himself does rely on this general principle, he cannot consistently refuse to apply it to the case of retributive justice. If, according to him, the fact that one does not deserve one's superior character means that one does not deserve any of the economic advantages that such a character might enable one to secure, then surely he must also allow that, since criminals do not deserve their bad characters, neither do they deserve the pumshments that those characters may lead them to incur. These considerations lead Michael Sandel to conclude that, "given Rawls' reasons for rejecting desert-based distributive arrangements, he seems clearly committed to rejecting desert-based retributive ones as well." 59

Sandel also argues, correctly in my view, that Rawls's citation of Feinberg in support of his claim that there is an asymmetry between distributive and retributive justice is misleading. ${ }^{60}$ Feinberg does claim that, where questions of desert are concerned, there is a difference of kind between the two cases, inasmuch as it is "nonpolar desert" that is relevant to distributive justice and "polar desert" that is relevant to retributive justice. $^{61}$ There is no suggestion, however, that these two types of desert stand in different logical relations either to institutions or to the concept of justice. Similarly, although Feinberg would agree with Rawls both that considerations of desert provide no grounds for objecting to an egalitarian distribution of benefits and that limited inequalities of the sort introduced by the difference principle can be justified on grounds that have nothing to do with desert, there is no reason to suppose that he would rest these judgments on any claim to the effect that desert is in principle irrelevant to what counts as a just distribution. Instead, as we have seen, Feinberg believes that considerations of desert support a thoroughgoing distributive egalitariamism but that they may be outweighed by just the sorts of maximin considerations that animate the difference principle. To be sure, I have argued that Feinberg is mistaken in thinking that he has shown desert to be egalitarian in its implications. ${ }^{62}$ But the fact remains that he takes the content of distributive justice to be fixed in part by reference to a prior notion of desert.

58. Nozick, supra note 34 , at 225 . For additional criticism, see the writings by Sher and Zaitchik, supra note 3 .

59. SANDEL, supra note 3, at 92. I endorsed Sandel's conclusion in Responsibility, Reactive Attitudes, and Liberalism in Philosophy and Politics, supra note 2, at $306 \mathrm{n} .7$.

60. See SANDEL, supra note 3 , at 90 n.3.

61. Feinberg, supra note 5, at 62 .

62. See supra Part I. 
It is worth repeating that, when Sandel and other critics argue that Rawls's treatment of desert in the distributive case generalizes to the retributive case as well, they tend to interpret him as advocating a purely institutional view of desert in the distributive context and as offering an argument for that view which appeals to the general principle that a desert claim cannot be valid unless the underlying desert basis is itself deserved. As I indicated in Part III, I find the first of these interpretive claims misleading, and as I will argue in Part VI, I believe that there is room to doubt the second. What is more important for my purposes, however, is that neither the purely institutional view nor the putative general principle belongs to the Liberal Theory as I have described it. In the next Part, I will propose a rationale for that theory and, more specifically, for its claim that there is an asymmetry between distributive and retributive justice with respect to the role of desert. Then, in the final Part, I will ask whether the Liberal Theory is committed to an argument of the sort that the critics impute to Rawls, an argument appealing to the general principle that a valid desert claim must be supported by a desert basis that is itself deserved. If not, and if an independent rationale for the Liberal Theory is indeed available, then egalitarian liberalism may be free to claim just what Rawls says it claims-namely, that desert plays a less fundamental role in relation to distributive justice than it does in relation to retributive justice.

\section{$\mathrm{V}$}

\section{HOLISM, INDIVIDUALISM, AND DESERT}

The Liberal Theory comprises three claims: an affirmation of legitimate expectations, a rejection of prejusticial desert in the context of distributive justice, and an acceptance of prejusticial desert in the retributive context. The first of these claims is uncontroversial. No one argues that just institutions should fail to honor the expectations to which they have given rise. It is the second and third claims, taken together, that imply that there is an asymmetry between distributive and retributive justice with respect to the role of desert. These claims are, of course, more controversial.

I want to explore a rationale for the second claim that is suggested by, though not explicitly articulated in, the work of Rawls and other egalitarian hiberals. ${ }^{63}$ It rests on a conviction that there is a fundamental difference between the justificatory bases for claims of desert and claims of distributive justice, respectively. As we saw earlier ${ }^{64}$ Feinberg asserts that the basis of a valid desert claim must always be some characteristic of or fact about the deserving person. We can express this point by saying that the basis for a claim of personal desert must be individualistic. As Feinberg

63. See, for example, the writings of Dworkin and Nagel, supra note 3.

64. See supra text accompanying notes 6-7. 
notes ${ }^{65}$ this does not mean that the desert basis cannot consist in some fact about the relations between the subject of the desert claim and other people. The fact that an individual has performed more skillfully than others in some competitive event, for example, may indeed be the basis for a claim about what that individual deserves. Even when the desert basis consists in a relational fact, however, it must still be individualistic in the sense that the fact in question must be a fact about the subject of the claim. Although the claim that an individual deserves a certain benefit implies that he ought, pro tanto, to receive it, Feinberg emphasizes that not every judgment to the effect that an individual ought to receive a certain benefit has an individualistic basis. For example, the fact that giving a certain benefit to $A$ will prevent something bad from happening to $B$ and $C$ cannot be the basis for a claim that $A$ deserves the benefit, but it may nevertheless be a (nonindividualistic) reason why $A$ ought-either pro tanto or all things considered-to get it. In short, the reasons in favor of providing some benefit to a given person may be either individualistic or nonindividualistic; considerations about what the person deserves are individualistic reasons.

Now I believe that it is possible to see the Liberal Theory's second claim as motivated by a conviction that, whereas desert is individualistic, distributive justice is holistic in the sense that the justice of any assignment of economic benefits to a particular individual always depends-directly or indirectly - on the justice of the larger distribution of benefits in society. In Rawls's theory of justice, this conviction is reflected in the claim that distributive shares should be treated as a matter of pure procedural justice ${ }^{66}$ and that provided the basic structure is just, any distribution of goods that results is also just. This means that, for Rawls, the principles of distributive justice do not apply to "a single transaction viewed in isolation." ${ }^{67}$ The justice or injustice of allocating a particular economic benefit to a given individual will always depend instead on whether that allocation is part of an overall distribution that is produced by a basic structure conforming to Rawls's principles of distributive justice. ${ }^{68}$

The case for conceiving of distributive justice in holistic terms is partly moral and partly empirical. It derives in part from a strong sense of the equal worth of persons and from a firm conviction that in a just society

65. See Feinberg, supra note 5, at 59 n.6.

66. Pure procedural justice obtains when there is no independent criterion for a just or fair outcome, but when instead there is a just procedure, and any outcome that results from carrying out the procedure is itself just. This is contrasted with cases in which there is an independent criterion for what would count as a just or fair outcome; in such cases, of course, one looks for a procedure that will lead to the just outcome so understood. See RawLs, supra note 1, at 83-90.

67. Id. at 87.

68. I have discussed the holism of Rawls's distributive theory at greater length in Rawls and Utilitarianism, in The CAMBridge Companion to RAwLs (Samuel Freeman ed, forthcoming). 
all citizens must enjoy equal standing. It also derives from a conviction that, in the circumstances of moderate scarcity of resources that are typical of human societies, citizens' material prospects are profoundly interconnected through their shared and effectively unavoidable participation in a set of fundamental practices and institutions-the economy, the legal system, the political framework-that establish and enforce the ground rules of social cooperation. People's prospects are seen as connected in at least three ways. First, people's productive contributions are mutually dependent in the sense that each person's capacity to contribute depends on the contributions of others. ${ }^{69}$ Second, the economic value of people's talents is socially determined in the sense that it depends both on the number of people with similar talents and on the needs, preferences, and choices of others. Third, people's expectations of material gain are linked in the sense that virtually any decision to assign economic benefits to one person or class has economic implications for other persons and classes. The holist concludes that, in light of these moral and empirical considerations, it makes no normative sense to suppose that there could be, at the level of fundamental principle, a standard for assigming such benefits that appealed solely to characteristics of or facts about the proposed beneficiaries. Yet that is precisely what a prejusticial conception of desert would have to be. Accordingly, the holist denies that there is any legitimate conception of this kind that is pertinent to questions of economic benefit. Instead, the norms of distributive justice must be thought of as specifying the contours of a fair social framework for the allocation of scarce material resources among citizens of equal worth and standing.

Rawls sometimes suggests that his rejection of prejusticial desert is consistent with the way in which distributive justice has traditionally been understood..$^{70}$ Although I believe that this is an overstatement, there are some things to be said in its favor. The very term "distributive justice," as Robert Nozick has emphasized in objecting to it ${ }^{71}$ appears to import a nonindividualistic perspective. And as we noted earlier, the idea that desert has a less central role to play in distributive than in retributive justice gains support from a very natural view of the distinctiveness of the criminal law. Nevertheless, it seems implausible to deny that people have ever interpreted justice as requiring economic benefits to be assigned on the basis of a prior conception of desert. What the Liberal Theory is best understood as claiming is that, as egalitarian ideas have become more securely entrenched within moral thought, and as people's participation in social

69. Thus, Elizabeth Anderson writes: "From the point of view of justice, the attempt, independent of moral principles, to credit specific bits of output to specific bits of input by specific individuals represents an arbitrary cut in the causal web that in fact makes everyone's productive contribution dependent on what everyone else is doing." Anderson, supra note 3, at 321 .

70. See RAwLs, supra note 1, at 10-11; see also id. at 313.

71. See Nozick, supra note 34 , at $149-50$. 
institutions of ever increasing comprehensiveness and complexity has made the interdependence of their fortunes impossible to ignore, the idea that economic benefits may justly be assigned on the basis of an individualistic standard of desert has, quite simply, ceased to be tenable. The point is not that nobody has ever subscribed to this idea but rather that in our moral and social world the idea no longer makes sense, if it ever did.

Clearly there are many questions that might be raised about the force of this argument for a holistic interpretation of distributive justice. For the purposes of this Essay, however, what is important to emphasize is that the considerations which have been cited in support of distributive holism do not provide comparable support for a holistic approach to retributive justice. The argument for distributive holism depends on three important assumptions. The first is that distributive justice is concerned with the proper division of social advantages-that is, with the allocation of things that people are presumed to want. The second assumption is that questions of allocation arise primarily for societies that find themselves in conditions of moderate scarcity that make it impossible for them fully to satisfy the demand for such advantages. And the third assumption is that, because goods are scarce and their allocation is heavily dependent on social institutions, any provision of advantages to some may affect the supply available for others. In short, the problem of distributive justice is seen as the problem of how to allocate scarce goods among moral equals.

By contrast, the problem of retributive justice does not concern the allocation of advantages at all, and it is not a problem posed by conditions of scarcity. To be sure, the "supply" of punishment is not, in principle, unlimited, and so punishing some may make it more difficult to punish others. But since punishment is a burden rather than a benefit, the problem of retributive justice is not a problem of limited supply; supply can safely be assumed to exceed demand. (That is, the supply of punishment may be assumed to exceed people's demand that they themselves be punished, although-as every American politician knows-it may not exceed their demand for the punishment of others). The problem of retributive justice is not the problem of how to allocate a limited supply of benefits aniong equally worthy citizens but rather the problem of how society can ever be justified in imposing the special burden of punishment on a particular human being. To put it another way, the establishment of penal institutions is a social response, not to allocative concerns, but rather to exercises of individual agency that society deems intolerable. ${ }^{72}$ The relevant question in this case is what, if anything, might justify such a response. ${ }^{73}$

72. To be sure, allocative concerns are sometimes raised about the operations of the criminal justice system, as for example when Paul Butler cites high rates of black imprisonment in an argument for racially based jury nullification. See Paul Butler, Racially Based Jury Nullification: Black Power in the Criminal Justice System, 105 YALE L.J. 677 (1995). In the end, however, Butler's argument rests 
One traditional answer to this question, of course, appeals to a prejusticial notion of desert. Society is justified in punishing people who have done things for which they deserve to be punished. There are, of course, many possible reasons for skepticism about this "retributivist" view of punishment and the underlymg conception of desert on which it relies. The Liberal Theory, as I am interpreting it, does not offer an affirmative defense of retributivism against all these forms of skepticism. However, it agrees that wrongful conduct-that is, conduct that would be wrong even if it were not illegal-is normally a necessary condition of just punishment. And there is nothing internal to the Liberal Theory which requires rejection of the retributivist idea that wrongdoers deserve to be punished. As we have seen ${ }^{74}$ it is the individualism of desert that is the source of the Liberal Theory's repudiation of prejusticial desert in the distributive context. For the reasons just discussed, however, the Liberal Theory has no quarrel with the individualism of the retributivist view-no quarrel, in other words, with its reliance on an individualistic conception of desert as the basis for just punishment. In this respect, then, the theory takes an asymmetrical attitude towards the role of desert in the distributive and retributive contexts. It is committed to denying that an adequate account of distributive justice can appeal to a prejusticial notion of desert, but it has no comparable commitment with respect to retributive justice.

not on a holistic understanding of retributive justice but rather on the claims (1) that crimes committed by blacks are often an excusable response to societal racism, and (2) that the criminal justice system enforces the criminal law in a selective and discriminatory manner. It is important to note that, even on an individualist understanding of retributive justice, the inconsistent application of retributive norms may itself be unjust.

73. In his reply to this Essay, Douglas Husak interprets this as a question about society's "complete justification for creating an institution of punishment." Douglas Husak, Holistic Retributivism, 88 CALIF. L. REV.991, 996 (2000). He then argues, plausibly enough, that considerations of overall cost are relevant to the latter question, and that it must therefore be answered holistically rather than individualistically. But the question I am concerned with here is not the question of society's all-things-considered justification for establishing institutions of punishment. $1 \mathrm{t}$ is rather the question of whether and when society's punishment of an individual is compatible with just treatment of that individual. Husak has not shown that this question must be answered holistically.

Husak also proposes the following parallel between distributive and retributive justice. In both cases, considerations of desert are individualistic and provide pro tanto reasons why individuals should receive certain benefits (or burdens). But in both cases, the all-things-considered justification for deciding actually to give them those benefits (or burdens) must depend on a variety of considerationsincluding considerations of desert but also including holistic considerations. However, this putative paralle1 underestimates the radicalism of the holist's rejection of distributive desert. The holist's claim, as I have construed it, is not that considerations of economic desert must be weighed in the balance with, and may be overridden by, considerations of a holistic character. The claim is rather that there is no prejusticial standard of desert that is relevant to questions of economic benefit. In other words, distributive justice is seen as holistic, not in the sense that holistic considerations may trump considerations of prejusticial desert, but rather in the sense that no considerations of prejusticial desert are thought to have any normative weight or standing at all. Since Husak does not wish to make a comparable claim about retributive justice, his argument does not undermine the suggestion that there is an asymmetry between the distributive and retributive cases.

74. See supra text accompanying notes 67-72. 


\section{VI}

\section{Must the Liberal Theory Be Generalized?}

We have now identified a rationale for denying that the principles of distributive justice make reference to a prejusticial concept of desert. Unlike the "general philosophical strategy" that Scanlon construes Rawls as employing ${ }^{75}$ the rationale we have identified seems not to apply to the retributive context. As we have seen, ${ }^{76}$ however, Rawls himself has often been interpreted as advancing an argument against distributive desert that is equally applicable to retributive justice, inasmuch as it implicitly relies on a putative general principle to the effect that a valid desert claim must be supported by a desert basis that is itself deserved. This principle, if accepted, would appear to provide just as much reason to reject the idea that criminals (prejusticially) deserve punishment as it does to reject the idea that people who are talented and hard-working (prejusticially) deserve economic rewards. For criminals presumably do not deserve to have the traits that lead them to commit crimes any more than the talented deserve their talents.

I do not know whether Rawls intended to make an argument of this kind. By itself, the fact that doing so would be inconsistent with his insistence on an asymmetry between distributive and retributive justice provides at least as much reason to doubt whether such an argument should be ascribed to him as it does to discount his claim of asymmetry. Furthermore, the textual evidence in favor of such an ascription seems to me inconclusive. The passages in Section 17 that have been interpreted as advancing such an argument do not do so explicitly, ${ }^{77}$ and I believe that it is possible to read those passages as making only the four claims mentioned earlier. ${ }^{78}$ In other words, there is room to doubt whether Rawls is also making the fifth and stronger claim that benefits obtained through the use of undeserved traits can never themselves be deserved.

Nevertheless, it is possible that he did mean to advance such an argument. Certainly it is clear that he possesses a strong sense of the arbitrariness of fortune, and one of his central themes is the unfairness of allowing the distribution of natural talents and traits-a distribution that does not itself have any normative basis-to influence people's material prospects to an extent that is incongruous with their status as moral equals. In his eagerness to undercut our tendency to treat such natural facts as morally dispositive, Rawls may perhaps have yielded to the temptation to offer an argument that was too strong for his own purposes.

\footnotetext{
75. Scanlon, supra note 55, at 188; see supra text accompanying notes 56-57.

76. See supra text accompanying notes 57-59.

77. See supra text accompanying note 32 .

78. See supra text accompanying note 34 .
} 
For the purposes of this Essay, what is important to emphasize is that the Liberal Theory, as I have interpreted it, neither explicitly advances nor implicitly relies upon such an argument. The Liberal Theory has reasons of its own for rejecting appeals to a prejusticial conception of desert in the specific context of distributive justice, and those reasons in no way depend on the idea that a valid desert claim must have a desert basis that is itself deserved. Thus, the considerations that have led commentators to conclude that Rawls's arguments about desert must inevitably generalize from the distributive to the retributive case simply do not apply to the Liberal Theory as I have interpreted it.

\section{ConClusion}

If the argument of this Essay is correct, then it is possible to deny that desert has a fundamental role to play in an account of distributive justice without committing oneself to a comparable claim about retributive justice. This means that Rawls's stated conviction that there is an asymmetry between distributive and retributive justice should be taken inore seriously than it sometimes has been. More generally, it suggests that egalitarian liberals like Rawls need not endorse the kind of wholesale skepticisin about desert that has sometimes been attributed to them. Furthermore, to the extent that liberal skepticism about distributive desert responds to a perceived contrast between the individualism of desert and the holism of distributive justice, much of the criticism of the liberal position has been misdirected. Insofar as that position relies on the rationale I have suggested, the interesting question is not whether a valid desert claim must have a desert basis that is itself deserved, but whether the case for distributive holism is compelling. ${ }^{79}$

In addition, there is the question of whether holistic and individualistic values can coherently be integrated into a umfied normative scheme. This question arises with particular urgency in relation to those categories of conduct-property crimes, for example-that appear to implicate both distributive and retributive justice. But the question is also important because, like desert, inany of the other values and norms that we recognize in daily life are responsive to features of individual character and conduct. Thus, it is important to ask whether one can do justice to those values

79. Nozick's criticism of "end-result" principles of distributive justice in chapter 7 of ANARCHY, STATE, AND UTOPIA, supra note 34, at 153-55, may be interpreted as in part a response to the holistic character of such principles. End-result principles, according to Nozick, assess the justice of a distribution solely by seeing whether the associated distributional matrix satisfies some structural criterion, rather than by taking into account historical information about how the distribution arose. However, a distributive theory nnay be holistic without counting as an end-result view in this sense. Indeed, I believe that this is true of Rawis's theory. I have discussed the point in Rawls and Utilitarianism, supra note 68. 
while treating the overall social framework as regulated by a holistic scheme of distributive principles.

Important as they are, however, these questions lie beyond the scope of this Essay. My aim here has been simply to call attention to an insufficiently examined rationale for the idea that desert has different roles to play in relation to distributive and retributive justice. 